\title{
CORRESPONDENCE
}

The Editor,

\author{
6 St. ANdRew Square, \\ Edinburgh, 2. 1st October 1956.
}

T.F.A.

Dear Sir,

\section{Holmes Ivory}

Not the least interesting part of Mr. Andrew R. Davidson's History of the Faculty of Actuaries in Scotland, 1856-1956, is his description of the break with the Institute of Actuaries by its Scottish members-a break which led directly to the formation of the Fraculty.

The correspondence at the time between the Institute and the Scottish members of its Council, recorded in full in Appendix IV (b) of the History, was conducted principally by Mr. Holmes Ivory, the "Scottish Vice-President" of the Institute. In view of the prominent part played by Mr. Ivory up to the final resignation of the Scottish members, others besides myself may ask why Ivory did not join the Faculty on its formation less than a year afterwards. The explanation seems to be worth recording.

Holmes Ivory was the first Manager of the National Fire Insurance Company of Scotland-later known as The Scottish National Insurance Company-which started business in May 1841. Persistent ill-health finally led to his resignation from the post of Manager in 1853, but he continued his connexion with his Office as Consulting Actuary and Auditor until his death in 1855. There is little doubt that if he had lived he would have taken a prominent part in the setting up of the Faculty. Here is one of those " might have beens" in which history abounds.

I have taken the above information from One Hundred Years : a brief Chronicle of the Scottish Union and National Insurance Company, 1824-1924, by W. Forbes Gray, F.R.S.E., F.S.A.(Scot.), where it is also recorded that Mr. Ivory's successor in office as Manager (and later as Actuary) of the Scottish National was John M. McCandlish, who was to become (in 1877) the first General Manager of the merger between his Office and the Scottish Union and (in 1887) the first President of the Faculty.

Yours faithfully,

D. SCRIMGEOUR. 